\title{
E-Book for Problem Based Learning to Improve Learning Outcome of the Students
}

\author{
Dwi Puji Astuti ${ }^{1}$, Siswandari $^{1}$, Djoko Santoso $\mathrm{Th}^{1}$ \\ ${ }^{1}$ Master's Degree Program in Economics Education, Sebelas Maret University, Surakarta, \\ Indonesia \\ itutsaijupiwd@gmail.com
}

\begin{abstract}
The rapid development of science and technology results in the change in all of life sectors, including education domain. The change of education domain occurs in learning media use in which electronic book (called e-book) starts to develop today replacing previous book used manually. The objective of research was to find out whether or not the use of PBL (Problem-Based Learning)-based e-book learning media can improve the learning outcome of student. This research was conducted using literature study on the relevant research journals. The problem of research was that the learning was still conducted conventionally and had not used varying learning media, so that the students understood poorly the learning material, leading to the low learning outcome. One of learning media innovations that could be used was PBL (Problem-Based Learning)-based e-book learning media. The PBL-based ebook learning media was one of innovative learning media that could provide active learning condition for the students. Through PBL-based e-book learning media, concept could be understood more in-depth, thereby improving the students' critical thinking and problem solving abilities, and learning outcome.
\end{abstract}

\section{Keywords: education; learning media; e-book; Problem-Based Learning; learning outcome}

\section{INTRODUCTION}

Information technology and communication has developed along with globalization. The competition occurring in globalization requires the development of human resource quality. Education is one of important thing in Human Resource development. One of educational problem prioritized is education quality. Government has taken some attempts of improving education quality. In line with National Education Vision, National Education Ministry wants to create a smart and competitive Indonesian in 2025, so that education is very important to nation's life sustainability [1]. A smart and comprehensive Indonesian is defined as the on with spiritual, emotional \& social, intellectual and kinesthetic intelligences. Therefore, the improvement of education quality is absolutely needed in developing human resource and in developing Nation Character Building) for the advance of nation. 
A nation's advance is inseparable from the role of more rapidly developing technology. It results in the change in all life sectors, including in education domain. The role of teacher is necessary to create education innovation through learning media to improve learning quality. Internet can be a medium of accommodating the existing learning media and internet can be modified in such a way that becomes a learning media that can support a learning process. The concrete form of technology's entry into education domain is the rapid development of electronic book replacing previous books used manually. The book formerly printed on paper is no converted into electronic book, called e-book.

E-book is the form of independent learning display organized systematically in electronic format $[2,3]$. The students can increase insight by means of learning the material presented in the form of e-book. E-book has some advantages compared with other types of education media: it can be used easily to learn anywhere and any time, it can improve the students' motivation and activeness, thereby improving their academic achievement $[4,5]$. Those advantages will motivate the students' learning independency and trigger their learning motivation in order to improve their learning outcome. Some scholars agree that e-book is a media needed for future education $[6,7,8,9]$.

This e-book should be supported with an appropriate and compatible learning model. Problem Based Learning (PBL) is an innovative learning model that can provide active learning condition for the students. Problem Based Learning model is the one characterized with real world problem as the context of students to learn critical thinking and problem solving skills and to acquire knowledge that can generate their curiosity $[10,11,12]$. Hou [13] states that one advantage of PBL is that the students have opportunity of participating actively in problem solving, so that the students are motivated in learning process. Martanti \& Priantinah [14] explains that the effectiveness of PBL learning model results from the students thinking and understanding the material more actively in group by means of investigating the problem surrounding, so that they obtain an in-depth and more meaningful impression on what they study.

Therefore, it is well-established that the existence of learning sources such as Problem Based Learning-based e-book is expected to help the students obtain learning experience and understanding the written tasks more actively and independently thereby facilitating the teachers in organizing teaching-learning process.

\section{DISCUSSION}

\section{E-Book}

The development of technology and information gradually replaces printed media with digital media. Information and publication originally documented and distributed through printed paper sheet now start to use electronic media as its alternative substitute. One of those media is e-book or called digital book.

E-book is one of technology utilizing computer to display multimedia information in brief and dynamic form [15]. Meanwhile, Almadani [16] states that e-book is a form of book that can be opened electronically using computer. Borchers [17] states that electronic book is a hardware and software system that can present textual information in large volume to the users and enable the users to explore information contained in it. 
E-book is usually an electronic version of printed book, but sometimes a book is published in digital form only without printed version.

Electronic book or e-book offers the students, teacher, and schools the supplemental media to support or to improve learning process. E-book can integrate visual, graphic, image, animation, and movie shows so that the information presented is richer than the conventional book does.

\section{Advantages of E-Book}

Every learning media of course has advantages and disadvantages in its use. Ebook has advantages different from other media. Despite no guaranty that e-book will replace all printed book immediately, replacing the existing printed book form with electronic book is inevitable, and will occur as soon as possible. Several advantages of e-book learning media, according to Onggo [18], are:

1. Flexibilities, e-book facilitates everyone to have mobile and portable library.

2. Function, the function of e-book is dependent on its manufacturer's program and the type of electronic document prepared, in which the programs can search for, complete information, change size, underline text, increase the font size, bookmark, use links and print it.

3. Easiness, e-book facilitates the users to fill in any information online.

4. Price, the cost of marketing e-book massively is cheaper than that using printed version.

5. Space, e-book has space capacity in hard disk of computer because entire encyclopedia can be stored. In addition, it can save the file storage space, money, time to remove, sort, edit, and replace file or content of e-book.

6. Availability, when compared with printed book, e-book is more efficient as it is prepared in electronic or digital form.

7. Easy to publish, the publication of e-book is very efficient and economic, and can increase the quantity and the variation of information.

8. Conservation, e-book can help in natural conservation process and reduce pollution due to manufacturing process.

E-book has some strengths (advantages) compared with other education media types: easy to use to learn anywhere and anytime [19]. In addition, e-book can be designed well to improve the students' activeness, to classify the students, so that the students can learn independently to help the development of learning process well. It is line with Ebied \& Rahma [20] stating that e-book has advantages as: improving the students' motivation to learn developing academic achievement such as using multimedia with e-book, accessible, organizing, finding title and text easily in e-book, and contained in tablet and cellular phone making it usable anywhere and anytime.

\section{Problem Based Learning (PBL)}

Problem-based learning is defined as the learning occurring through the process of trying to solve or manage problem in real life [21]. Person \& Bignell [22] state "PBL takes place within the context of structured tasks aligned with courses or real-world scenarios linked with course material".

The application of PBL emphasizes on the collaboration in building knowledge and team-based learning utilizing new collaborative instruments (such as blog, virtual 
world, simulation, gaming, discussion forum, chat, and etc) can facilitate the students to interact and to increase scope and gain expected from the PBL process it self [23,24].

The students' learning achievement improves more than the learning process using conventional method, as PBL is a learning model involving the students directly in a subject giving practical task [25]. It is in line with Asyari et al.'s [26] study concluding that PBL model can encourage the students to think critically through planning, debating, questioning, problem solving, analyzing and giving solution to the problem encountered. PBL model teaches the students to learn solving problem either individually or in group in learning process so that the learning process become more joyful and meaningful.

Problem Based Learning model is designed to develop skill to participate in democratic social process through emphasizing on the combination of interpersonal skill and academic investigation [27]. One advantage of PBL method is that the students have opportunity of being involved actively in problem solving therefore the students are motivated in learning process [28]. Martanti \& Priantinah [29] explain the effectiveness of PBL learning model lies on the students thinking and understanding material more actively in group by means of investigating the problem surrounding thereby obtaining in-depth and more meaningful impression about what they study.

\section{Learning Outcome}

Learning outcome is an integral part of learning process. The learning outcome is an ability the students have after the students receive knowledge in learning process. Kettunen, Mertanen, \& Penttila [30] state "Learning outcomes are statements which are used to describe specifically what is expected from a learner in form of understanding, knowledge and know-how at the end of a certain period of learning". Learning outcome is what an individual knows, understands and ability of doing something in the end of learning process and defined as knowledge, ability and competency [31].

Learning outcome is cognitive, affective, and psychomotor competency or ability the students have after receiving learning experience [32,33]. Learning outcome involves cognitive, affective and psychomotor domains [34,35,36]. Teacher is responsible for the outcome of learning occurring in school or specifically in classroom. The students' material mastery becomes the parameter of the extent to which the students understand and receive knowledge in learning activity. Learning process affects the students' learning outcome. Therefore the component of learning should be used maximally as the attempt of improving learning quality.

\section{Problem Based Learning-based E-Book Learning Media to Improve The Learning Outcome of Students}

E-book is organized systematically by presenting independent teaching learning in electronic format [37]. E-book development in an interactive digital technology us supported with attractive layout display and have more content in it thereby facilitating the e-book learning media users.

Problem Based Learning-based E-book is presented corresponding to the characteristics of Problem Based Learning model. The characteristics of PBL learning model are elaborated below. 
TABLE I. CHARACTERISTICS OF PBL LEARNING MODEL

\begin{tabular}{|ll|}
\hline \multicolumn{1}{|c|}{ Phase } & \multicolumn{1}{c|}{ Teacher Behavior } \\
\hline $\begin{array}{l}\text { Phase 1: Giving the students the } \\
\text { problem orientation }\end{array}$ & $\begin{array}{l}\text { Teachers discuss the learning objective, describing and } \\
\text { motivating the students to participate in problem solving } \\
\text { activity. }\end{array}$ \\
\hline $\begin{array}{l}\text { Phase 2: Organizing the students to } \\
\text { investigate }\end{array}$ & $\begin{array}{l}\text { Teachers help the students define and organize learning } \\
\text { task related to the problem }\end{array}$ \\
\hline $\begin{array}{l}\text { Phase 3: Helping independent and } \\
\text { group investigation }\end{array}$ & $\begin{array}{l}\text { Teachers encourage the students to obtain appropriate } \\
\text { information, to conduct experiment, and to find } \\
\text { explanation and solution. }\end{array}$ \\
\hline $\begin{array}{l}\text { Phase 4: Developing and } \\
\text { presenting the result }\end{array}$ & $\begin{array}{l}\text { Teachers help the students plan and prepare the } \\
\text { appropriate outcomes such as report, video recording, and } \\
\text { models in helping them deliver it to others. }\end{array}$ \\
\hline $\begin{array}{l}\text { Phase 5: Analyzing and evaluating } \\
\text { the problem solving process }\end{array}$ & $\begin{array}{l}\text { Teachers help the students reflect on their investigation } \\
\text { and process they use. }\end{array}$ \\
\hline
\end{tabular}

Source: Arends [38]

Considering the elaboration above, it can be explained that learning process using PBL learning model involves the students' active participation in solving the problems given through task and exercise. PBL learning model will change conventional into more active learning pattern. PBL learning model practices the students to solve the real problem intended to construct their own knowledge, to practice their critical thinking skill and problem solving ability.

It is in line with Asyari, et al. [39] stating that PBL learning is a learning strategy that can stimulate the students to find problem, analyze, integrate, and solving problem in group. The main target of PBL learning model is students, so that teachers serve as facilitator or learning activity guide. Learning activity will be more alive as the learning is dominated by students. In addition, the students will express their opinion more bravely without the fear of error.

Problem Based Learning-based e-book learning media is used as an independent learning course thereby improving the understanding and the competency to be mastered by the students in the learning process. The development of Problem Based Learning-based e-book learning media can evidently improve the students' learning outcome $[40,41,42]$. Such the media development is intended to improve in-depth understanding on economic lesson concept, and critical thinking and problem solving abilities. Park, Kim \& Yoo [43] conducting a study in Korea found that digital book gives positive response when it is used concomitantly with Problem Based Learning Model.

Problem Based Learning-based e-book learning media can help the learning activity; it can be in soft file with .exe (executable file) format that can be operated using computer, laptop and smartphone. The Problem Based Learning-based e-book learning media facilitates the students to learn independently; it is presented clearly contains questions designed meaningfully and attractively to motivate the students to learn thereby optimizing their learning outcome. In addition, another benefit obtained from using the Problem Based Learning-based e-book learning media in learning process is that it increases and expands the knowledge vocabularies taught by teachers or educators, stimulates educators to think critically in solving problem 
related to the problem existing in real world so that the graduate output has good competitiveness.

\section{CONCLUSION}

Considering the literature study above, it can be concluded that there is a need for creating education innovation through learning media. One of learning media to support learning activity and to involve the students actively is Problem Based Learning-based e-book media. The Problem Based Learning-based e-book media facilitates the students to learn independently presented clearly, containing questions designed meaningfully and attractively, and can stimulate the students to think critically. Using the Problem Based Learning-based e-book media can improve the material understanding and the competency mastery in learning process thereby improving the learning outcome of students maximally.

\section{REFERENCES}

[1] Kemendiknas. (2010). Renstra Kemendiknas. Jakarta: Kemendiknas.

[2] Andrea, Jenny, Joanna \& Amelia. (2016). Using E-Books to Creat Shared Learning Experiences Between Student of Differing Abilities. Journal of Occupational Therapy, Schools, \& Early Intervention, 9 (1), 12-18.

[3] Letchumanan, M., \& Tarmizi, R. A. (2010). Utilization Of E-Book Among University Mathematics Students. Journal Elsevier: Social and Behavioral Sciences, 8 (1), 580-587.

[4] Nguyen, N. (2015). Designing and Using Interactive E-Books in Vietnam. International Journal of Learning, Teaching and Educational Research, 11 (1), 75-98.

[5] Ebied, M., \& Rahman, S. A. A. (2015). The Effect of Interactive E-Book on Students' Achievement at Najran University in Computer in Education Course. Journal of Education and Practice, 6 (19), 71-82.

[6] Beadenkopf, S. (2009). e-Books: Wave of the future or just a passing shower? In I. Gibson et al. (Eds.). Proceedings of Society for Information Technology Teacher Education International Conference, hlm. 2429-2434. Chesapeake, VA: AACE.

[7] King, D. (2010). Ebooks: Advice From The Educational Front. Information Today, 27 (11), 48.

[8] Rowlands, I., Nicholas, D., Jamali, H., \& Huntington, P. (2007). What do faculty and students really think about e-books?. Aslib Proceedings, hlm. 489-511. University College London.

[9] Warburton, D. (2007). The Electronic Book. International Journal of Productivity and Performance Management, 40 (1), 6-8.

[10] Nurhadi. (2003). Pendekatan Kontekstual. Jakarta: Departemen Pendidikan Nasional.

[11] Husamah. (2013). Desain Pembelajaran. Jakarta: Prestasi Pustaka.

[12] Sugiyanto, H. (2009). Model-Model Pembelajaran Inovatif. Surakarta: Yuma Pustaka.

[13] Hou, J. (2014). Project and Module Based Teaching and Learning. International Journal of Social, Behavioral, Educational, Economic, Business and Industrial Engineering, 8 (3), 791-796.

[14] Martanti, I. W., \& Priantinah, D. (2014). Penerapan Model Pembelajaran Problem Based Learning Untuk Meningkatkan Pemahaman Konsep Dan Motivasi Belajar. Jurnal Pendidikan Akuntansi, 7 (1), 93-105.

[15] Putra, N. (2012). Reseacrh \& Development, Penelitian dan Pengembangan Suatu Pengantar. Jakarta: PT. Raja Grafindo Persada.

[16] Almadani, F. (2014). Buku Digital Interaktif. Diakses dari http://firmanalmadani.wordpress.com pada tanggal 28 April 2017.

[17] Borchers, J. O. (1999). Electronic Books: Definition, Genre, Interaction Design Pattern. Austria: Linz University.

[18] Onggo., B. J. (2007). Success With E-book. Bandung: Syaamil Cipta Media. 
[19] Nguyen, N. (2015). Designing and Using Interactive E-Books in Vietnam. International Journal of Learning, Teaching and Educational Research, 11 (1), 75-98.

[20]Ebied, M., \& Rahman, S. A. A. (2015). The Effect of Interactive E-Book on Students' Achievement at Najran University in Computer in Education Course. Journal of Education and Practice, 6 (19), 71-82.

[21] Sadlo, G. (2014). Using Problem Based Learning During Student Placement to Embed Theory in Practice. PBLH: The Higher Education Academy, 2 (1), 6-19.

[22] Person, V., \& Bignell, S. (2011). Using Problem Based Learning within 3D Virtual World. An Internasional Journal of Industrial Robots, 30 (1), 241-246.

[23] Carbonell, K. B., Dailey-Hebert, A., Gerken, M., \& Grohnert, T. (2015). Problem-based Learning in hybrid, blended, or online courses: Instructional and change management implications for supporting learner engagement, in increasing student engagement and retention in e-learning environment: web 2.0 and blended learning technologies. Cutting-edge Technologies in Higher Education, 6G, 359-386.

[24] Schechter, C. (2011). Switching Cognitive Gears. Journal of Educational Administration, 49 (2), 143-165.

[25] Titisari, K. H.,Wijayanti, A., \& Chomsatun, Y. (2013). Model Pembelajaran Akuntansi Untuk Meningkatkan Kompetensi Mahasiswa. Jurnal Buletin Studi Ekonomi, 18 (2), 85-190.

[26] Asyari, M., Muhdhar, M. H. I. Al., Susilo, H., dan Ibrohim. (2016). Improving Critical Thinking Skills Through the Integration of Problem Based Learning and Group Investigation. International Journal for Lesson and Learning Studies, 5 (1), 36-44.

[27] Sejpal, K. (2013). Models Teaching: The Way of Learning. International Journal for Research in Education, 2 (3), 18-24.

[28] Hou, J. (2014). Project and Module Based Teaching and Learning. International Journal of Social, Behavioral, Educational, Economic, Business and Industrial Engineering, 8 (3), 791-796.

[29] Martanti, I. W., \& Priantinah, D. (2014). Penerapan Model Pembelajaran Problem Based Learning Untuk Meningkatkan Pemahaman Konsep Dan Motivasi Belajar. Jurnal Pendidikan Akuntansi, 7 (1), 93-105.

[30] Kettunen, J., Mertanen, L. K., \& Penttila, T. (2013). Innovation Pedagogy and Desired Learning Outcomes in Higher Education. On The Horison, 21 (4), 333-342.

[31]Lile, R., \& Bran, C. (2014). The Assesment of Learning Outcomes. Procedia-Social and Behavioral Sciences, 163, 125-131.

[32] Sudjana, N. (2011). Penilaian Hasil Proses Belajar Mengajar. Bandung: PT Remaja Rosdakarya.

[33] Kunandar. (2013). Penilaian Auntentik (Penilaian Hasil Belajar Peserta Didik Berdasarkan Kurikulum 2013). Jakarta: PT Raja Grafindo Persada.

[34]Rusman. (2013). Belajar dan Pembelajaran Berbasis Komputer Mengembangkan Profesionalisme Guru Abad 21. Bandung: Alfabeta.

[35] Susanto, A. (2013). Teori Belajar dan Pembelajaran di Sekolah Dasar. Jakarta: Kencana Prenada Media Group.

[36] Karwati, E., \& Priansa, D. J. (2014). Manajemen Kelas (Classroom Management) Guru Profesional yang Inspiratif, Kreatif, Menyenangkan, dan Berprestasi. Bandung: Alfabeta.

[37] Cumaoglu, G., Sacici, E., \& Torun, K. (2013). E-Book Versus Printed Materials: Preferences of University Students. Contemporary Educational Technology, 4 (2), 121-135.

[38] Arends, R. I. (2008). Learning to Teach Belajar untuk Mengajar Edisi 7 Jilid 1. Terj. H.P. Soejipto \& S. M. Soejipto. Yogyakarta: Pustaka Belajar.

[39] Asyari, M., Muhdhar, M. H. I. Al., Susilo, H., dan Ibrohim. (2016). Improving Critical Thinking Skills Through the Integration of Problem Based Learning and Group Investigation. International Journal for Lesson and Learning Studies, 5 (1), 36-44.

[40]Zahara, N., Djufri., \& Muhibbuddin. (2014). Optimalisasi Pembelajaran dengan E-Book dan Media Pembelajaran Berbasis Multimedia Untuk Meningkatkan Hasil Belajar Peserta didik Kelas X SMA Pada Materi Dunia Tumbuhan. Jurnal Biotik, 2 (2), 77-137.

[41] Putrawansyah, F., Zulkardi., \& Sardianto M. S. (2016). Pengembangan Digital Book Berbasis Android Materi Perpindahan Kalor Di Sekolah Menengah Atas. Indonesian Journal on Networking and Security, 5 (4), 39-48. 
[42] Johnson, G. Marie., \& Buck, G. H. (2014). Electronic Books versus Paper Books: Pre-Service Teacher Preference for University Study and Recreational Reading. International Journal of Humanities Social Sciences and Education (IJHSSE), 1 (8), 13-22.

[43] Park, Chan-Seok., Kim, Mihye., \& Yoo, Kwan-Hee. (2012). Design and Implementation of a Problem-based Digital Textbook. International Journal of Software Engineering and Its Applications, 6 (4), 213-222. 